http://dx.doi.org/10.12775/szhf.2020.026

\author{
TOMASZ JARMUŻEK \\ Nicolaus Copernicus University in Toruń \\ E-MAIL: JARMUZEK@UMK.PL, ORCID: OOOO-0003-3456-3859 \\ Tomasz Kupś \\ Nicolaus Copernicus University in Toruń \\ E-MAIL: KUPS@UMK.PL, ORCID: 0000-0001-6773-1180
}

\title{
The Heritage of Jerzy Łośs Philosophical Logic and the Polish Question An Introduction to the Volume
}

\section{Historical Context}

Poland has produced a number of world-class scientists and scholars who have developed several influential theories, made important discoveries, and conceptualised numerous innovations. However, the ideas of Polish academicians from the $19^{\text {th }}$ and $20^{\text {th }}$ centuries often faced the same fate as Poland itself. Despite their pioneering nature, these results were not fairly received in the world or, at times, even in the country. They were overshadowed by

This title is a paraphrase of the famous historic statement "The Elephant and the Polish Question”. 
other research centres that were more influential or better organised. Thus, just as Poland suffered - first under foreign rule in the period of partitions and then, after the interwar period, under a totalitarian yoke - so did Polish scientific discoveries. They were unable to impact the outer environment autonomously, lost their due position and gained no due recognition. The events of the $20^{\text {th }}$ century were particularly tragic: a number of outstanding Polish scientists and scholars were murdered or forced to emigrate, which abruptly interrupted or disturbed the achievement and tradition transmission process.

This volume attempts to do justice to the achievements of one such Polish academic research forgotten by history. Our intention is not only to present it to the world but, first and foremost, to present it as a source of valuable research inspiration for the next generations of scholars. The achievement we are referring to is the philosophical logic of Jerzy Łoś, a philosopher and mathematician whose roots were in Lvov. The reception, study and promotion of his heritage serves as a model of scientific perfectness, in line with the highest global standards. At the same time, the research inspired by Łośs heritage shows that innovative research in humanities is perfectly possible. Without losing its traditional perspective, such research is a part and parcel of the prevailing interdisciplinary trend that breaks through the classical divisions in science and forms multidisciplinary research teams.

Jerzy Łoś is a Polish logician born in Lvov. His studies at the Jan Kazimierz University in Lvov were interrupted by the outbreak of World War II. After the war, he continued his education at the Maria Curie-Skłodowska University in Lublin. He worked in Wrocław following this and later on in Torun and Warsaw. Łośs many results and achievements are renowned in logical circles. These include his significant findings in algebra and mathematical logic. Over the initial years of his research career, Łoś was extremely successful in the field of philosophical logic, where he discovered and described the very first systems of philosophical logic - temporal logic and epistemic logic. This research was carried out in the late 1940s.

Naturally, the results obtained by Łoś in the 1940s could not become immediately popular abroad due to the Iron Curtain. However, except for a few early foreign, and also seminal, works on philosophical logic, almost none of the later foreign works recognise Łoś as the pioneer in temporal and epistemic 
logic. His results are usually completely overlooked. This is particularly striking in works of a historical nature, which, by definition, should include information on all the ground-breaking achievements in a given field.

\section{Pioneering Ideas by Łoś and Their Reception}

The works by Jerzy Łoś from the 1940s being discussed here are as follows:

(a) "Podstawy analizy metodologicznej kanonów Milla" (pp. 269-301, Annales Universitatis Mariae Curie-Skłodowska, 2.5. F, Lublin 1947): a paper on temporal logic published in $1947 .{ }^{1}$

(b) "Logiki wielowartościowe a formalizacja funkcji intensjonalnych" ("Multi-valued logics and the formalism of intensional functions") (pp. 59-78, Kwartalnik Filozoficzny XVII, 1-2, Kraków 1948): a paper on epistemic logic published in 1948.

The author intended the first paper to focus on logic in the empirical sciences. In addition to achieving this goal, it also proposed the first in the history system of temporal logic, i.e., a logic that uses the parameter of time in its arguments. With regard to the second paper, Łoś intended it to describe assertion logic, i.e., a logic that takes into account, in acceptable lines of reasoning, the relationships between the cognitive agent and the various propositions. In the history of logic, this was one of the very first systems of epistemic logic (hence, a logic of propositions on the relationships between the knowing agent and the objects of its knowledge). In the first period of work on epistemic logic, such logics were called logics of assertions or beliefs. ${ }^{2}$

Łośs primary aim in his works was to use a logical operator that links propositions to names. This operator - which we refer to as the Łośs

1 See the English translation: Jerzy Łoś, "The foundations of a methodological analysis of Mill's methods", in: Twenty-Five Years of Logical Methodology in Poland, eds. Marian Przełęcki, Ryszard Wójcicki (Dordrecht: D. Reidel Publishing Company, 1977), 291-325.

${ }^{2}$ It is worth mentioning that these pioneering papers were published over 70 years ago. So, we recently celebrated the $70^{\text {th }}$ anniversary of the creation of the first systems of temporal logic and, respectively, of epistemic logic. 
operator - enables one to express many relationships that cannot be stated by propositional connectives or quantifiers.

Since the Łośs operator links the name to the proposition, the fact that propositions may be interpreted at various reference points allows one to interpret the logics with the Loś's operator in several different ways. Originally, the names in the range of the Łośs operator were interpreted as time intervals for the temporal logic or as the knowing agents or beliefs in the case of epistemic logic. However, they may represent any arbitrary context in which the logical value of propositions is assessed.

Although the aforementioned works by Łoś were written in Polish, the central notions of these papers reached foreign scholars through their English reviews. For instance, Arthur Prior, the creator of tense logic, mentioned Łośs paper in his fundamental work (Past, Present and Future, 1967, p. 212), knowing it only from the review by Henryk Hiż (Review of: Jerzy Łoś, Podstawy analizy metodologicznej kanonów Milla, 1951, pp. 58-59). Nicholas Rescher, an influential logician and philosopher and almost a contemporary of Łoś, still considered this paper pioneering and mentioned it in his works (e.g., in his book Temporal Logic, 1971, p. 12). Łośs paper on epistemic logic was reviewed as early as 1949 by Roman Suszko in the Journal of Symbolic Logic (1949, pp. 64-65). His ideas were also summarised by Prior in Formal Logic (1955, p. 313) and Rescher, who referred to this summary in his paper Assertion Logic:

The founder of assertion logic is the Polish logician Jerzy Łoś. In his important 1948 paper, Łoś developed what he called a logic of 'belief' or 'assertion' upon the following basis. An $七$-operator was introduced with $\succeq_{x} p$ ' to mean 'the man $x$ believes (or: is committed to) the proposition p'. [(1968): "Assertion Logic" (in:) Topics in Philosophical Logic (D. Reidel Publishing: Dordrecht-Holland) pp. 250-286].

This way, Rescher recognised Łośs expertise and considered his paper important for epistemic logic. Unfortunately, over time, this understanding has lost its influence, and Łośs theories faded into obscurity for reasons that are unclear. In modern influential works, the achievements of Łoś are completely omitted. In fact, priority is accorded to authors of later works who were either directly or indirectly inspired by the ideas of the Polish logician. 
As mentioned earlier, it is particularly striking that there is no information on the subject in historical works.

One such example is Temporal Logic: From Ancient Ideas to Artificial Intelligence (Øhrstrøm and Hasle, 1995), a book on the history of temporal logic. Despite its historical nature, the book does not mention any of Łośs pioneering works. The situation is similar in an introduction to philosophical logic jointly written by several authors: The Blackwell Guide to Philosophical Logic (Goble, 2001). The book does not include a single reference to the Polish logician, not even in the section dedicated to temporal logic ("Temporal logic", pp. 203-223) or to epistemic logic ("Epistemic logic", pp. 183-202). Łoś has not been mentioned in the references in these parts either.

Under the respective entries of the influential online Stanford Encyclopaedia of Philosophy, the coverage of Łoś's discoveries has been far from accurate until very recently. His name was not mentioned under "temporal logic", neither in the entry text nor the references (Stanford Encyclopaedia of Philosophy). It was not until a polemic was made against the historical works that omit Łoś that some change was brought about ${ }^{3}$ and Łos appeared in the entry (although not in the references). However, he is still referred to as a forerunner of temporal logic rather than the creator of the first system of temporal logic. ${ }^{4}$

The name of Jerzy Łoś does appear in the introduction to the "epistemic logic" entry in the same encyclopaedia (Stanford Encyclopaedia of Philosophy) - among many other prominent logicians and philosophers involved in the work on epistemic logic; however, it is a single occurrence. In the entry text, neither is his knowledge logic system discussed nor are his works included in the references.

The above few examples only exemplify the number of such unfortunate cases. There is no doubt that Łośs pioneering works on philosophical logic have been almost completely forgotten abroad. In recent years, attempts have been made to remind the world and Poland of the philosophical logic of Jerzy Łoś - a result of the work on expanding and generalising Łośs ideas. Our attempts include two books and a series of papers on logics with the Łośs

3 See, e.g., Marcin Tkaczyk, Tomasz Jarmużek, “Jerzy Łoś positional calculus and the origin of temporal logic", Logic and Logical Philosophy 28 (2019): 259-276.

4 One of the works in our volume is devoted to this problem. See, Aleksander Parol, "The Influence on Jerzy Łoś on Early Developments in Temporal Logic". 
operator - the central notion of his logics. These works were carried out by scholars from the Nicolaus Copernicus University in Torun and from the John Paul II Catholic University of Lublin.

In the framework of cooperation between some of the authors within our research group, a research grant entitled Positional Logics - Meta-theory and Applications was carried out. This grant generalised the logics with the Łośs operator and resulted in a book (in Polish) - Normal Positional Logics. ${ }^{5}$ The book was awarded a distinction from the Jan Łukasiewicz Award Committee in a competition organised by the Polish Society of Logic and Philosophy of Science. The second book (also in Polish) is Jutrzejsza bitwa morska. Rozumowanie Diodora Kronosa. The book is devoted to the application of temporal logics to the history of antiquity. A considerable part of the book deals with the extension and application of logics with the Łośs operator. This book has been translated into English and published under the title On the Sea Battle Tomorrow That May Not Happen.

In the framework of cooperation between both centres, a number of papers have been written, either inspired by Łośs idea or providing a historical analysis of the problem or polemics; some of these are included in the references. Moreover, the historic proposals by Łoś and their extensions have been presented during many national and international conferences in various parts of the world.

\section{The Heritage of Jerzy Łośs Philosophical Logic}

This volume explores the original thought of Łoś and its extensions, including the first works by the Polish logician from the 1940s and his novel ideas on temporal and epistemic logic. This heritage also includes later works on philosophical logic by other authors who consciously make references to them or are inspired by Łośs discoveries - contemporary works in particular - although not limited to Polish authors.

5 Tomasz Jarmużek, Marcin Tkaczyk, Normalne logiki pozycyjne (Lublin: Towarzystwo Naukowe KUL, 2015). 
The philosophical logic heritage of Łoś is an example of interdisciplinary research in humanities with untapped potential for positive influence on the development of academic research and its reception in the society when duly promoted. Despite the mathematical logic method being applied to problems from within humanities (or at least close to them), such as the problem of knowledge or time, Łośs works are regarded as an important part of Polish humanities. For instance, it is symptomatic that Łośs fundamental text on temporal logic ("Podstawy analizy metodologicznej kanonów Milla") has been made available in an online repository of the Polish History Museum in the Humanities section (http://bazhum.muzhp.pl). Through its heritage and uniqueness in the world of academic achievements of the Lvov-Warsaw school, logic in Poland has been usually seen as an important discipline rooted both in the formal mathematical sciences and in philosophy and humanities. It is characteristic of this picture that departments and institutes of logic in Poland are affiliated to various faculties, either the faculty of mathematics or law or humanities.

This volume seeks to strengthen the influence of Polish logic in society, fortify its interdisciplinary character, invigorate the memory of past achievements and, simultaneously, encourage new undertakings that would extend the results and subjects from past research. Irrespective of the above, the stimulation and promotion of innovative research in humanities using formal methods is required. For Polish humanities, it is a natural trend - not only does it correspond with the achievements of the Lvov-Warsaw school of logic and philosophy but it may also be very practical today by applying mathematical humanities to the development of other areas of science, culture, education, economy and society. ${ }^{6}$

${ }^{6}$ We believe that the present volume of Studia $z$ Historii Filozofii may become the basis for a change in content on English and Polish websites on logic and philosophy where the corresponding entries may be complemented with information on the philosophical logic of Łoś. 


\section{Works Included in This Volume}

In our volume, we present four papers on different subjects that are linked by the philosophical logic heritage of Jerzy Łoś.

The paper "Jerzy Łośs Epistemic Logic and the Origins of Epistemic Logics" by Marek Lechniak tells the story of the creation of the first system of epistemic logic. Amongst the many classics in this field, Łoś historically holds the first place with his assertion logic. Characteristically, the first works on this subject are primarily syntactic and call for some groups of axioms and rules of inference, which are supposed to hold for the operator of knowledge/ assertion or belief. In his paper, Lechniak describes the system of Łoś and combines it first with later systems proposed by Rescher and then with the system proposed by Marciszewski. Moreover, the author analyses the postulates of Łoś in the context of the theory of rational behaviour. The tradition referred to by Lechniak is, in a way, forgotten with the creation of semantics of possible worlds and its use for the modelling of various propositional attitudes, including the knowledge of agents. However, since the approach to epistemic logic via the semantics of possible worlds generates numerous problems (e.g., the omniscience paradox) and the semantics itself seem to reach certain limits with respect to application, it appears that the original approach proposed by Łoś and developed by Rescher (among others) may become avant-garde in the deliberations on the modelling of knowledge and beliefs of agents, especially when the realisation operator is interpreted without making references to the possible worlds. ${ }^{7}$ The work of Lechniak is synthetic and provides a good compendium of the beginnings of epistemic logic.

In "Going Beyond the Dichotomy. Problems of Contemporary Sociology in the Context of the Proposals by Jerzy Łoś" by Krzysztof Pietrowicz and Joanna Szalacha-Jarmużek, the reader will find the answer to the question of why a certain element of the historical, philosophical and logical deliberations of Jerzy Łoś may be interesting from the point of view of contemporary

7 See, e.g., Mateusz Klonowski, Krzysztof Krawczyk, "Problem wszechwiedzy logicznej. Krytyka nienormalnych światów i propozycja nowego rozwiązania” (“The problem of logical omniscience. The critique of non-normal worlds and the proposition of new solution"), Filozofia Nauki 27, 1 (2019): 27-48. 
sociologists (or, more generally, representatives of social sciences). As the starting point for these deliberations, let us consider the following three research questions: (1) How can the philosophical perspective from decades ago be reasonably used by contemporary researchers in social sciences? (2) What is the relationship between philosophy and social sciences, sociology in particular, today? (3) Can sociologists make use of the philosophical logic achievements, including the ideas of Łoś?

In their paper, the authors address these questions, outline the context of the cooperation between sociologists and philosophers and describe the possibilities that open up when Łošs works are used for research in computational sociology. This work highlights the relationship between mathematical and abstract deliberations and qualitative phenomena. Thus, this text pertains to the formalisation of the immeasurable. Notably, the paper also alludes to other Polish classics. Apart from references to Florian Znaniecki, readers will learn about Klemens Szaniawski, who attempted to combine the Lvov-Warsaw school's tradition with sociology. The paper in question provides a more humanistic elaboration of certain original ideas on how the Łośs operator can be used in the social sciences, which the authors have already presented earlier but in a more formal manner. ${ }^{8}$

The next paper, "Epistemic Contextualism and Positional Logic" by Mateusz Klonowski and Rafał Palczewski, deals with the application of the Łośs operator to the problem of a particularly understood context. It is a natural application (given that the name in the Łośs operator refers to something with reference to what we interpret the proposition), although a new one. The context discussed here is that of the philosophical view "epistemic contextualism". A detailed discussion of this standpoint can be found in this work. Although epistemic contextualism bears some resemblance to logical pragmatics, there are some differences between these approaches. In the introductory part of their paper, the authors discuss contextualism, its various variants and the philosophical theses related to it. Clearly, it is a natural introduction to transferring this standpoint to logic. The work recalls earlier attempts of its formalisation based on modal logic. Further, a discussion is led on minimal

8 Jacek Malinowski, Krzysztof Pietrowicz, Joanna Szalacha-Jarmużek, "Logic of Social Ontology and Łośs operator”, Logic and Logical Philosophy 29 (2020): 239-258. 
positional logics, allowing one to introduce one's own perspective of epistemic contextualism, with semantics, which are simpler than in the modal approach and simultaneously allow for modelling the different properties of context, desirable in discussions on epistemic contextualism. To this end, the authors define the notion of the (positional) context model of an agent. Undoubtedly, the paper is only a pretext for further work, which must extend the positional context models of agent and leave a durable mark on the discussion on logical approach to epistemic contextualism.

Aleksander Parol's “The Influence of Jerzy Łoś on Early Developments in Temporal Logic" is a polemic on who created the first temporal logic system. As mentioned in the introduction, several historical texts have overlooked Jerzy Łoś. ${ }^{9}$ Influenced by polemics, some authors have recognised the contribution of Jerzy Łoś in more recent works without, however, admitting that he was the one who created the very first system of temporal logic and formulated some arguments. ${ }^{10}$ Parol's work is highly analytic, meticulously analysing the arguments of both sides and showing that negating the fact that the logic of Jerzy Łoś was the first temporal logic system results in too narrow a notion of temporal logic, which excludes virtually every logic other than tense logic. Moreover, Aleksander Parol discusses in detail the question of the influence of Łośs work on the works of Rescher, Urquardt and Prior. The direct and indirect impact of Łośs ideas has also been highlighted. This influence is also confirmed by the above-mentioned authors. The analytic line of reasoning contained in the paper gives Łoś priority in the construction of the temporal logic system and a significant influence on the development of these issues. This does not, however, change or trivialise the fact that Arthur Prior is the creator of tense logic, a very important branch of temporal logic.

In conclusion, if the Łośs operator is such a malleable tool that it can be interpreted as referring propositions to time, agents, pragmatic contexts or

9 For example, in: Peter Øhrstrøm, Per Hasle, Temporal Logic: From Ancient Ideas to Artificial Intelligence (Dordrecht: Kluwer Academic Publishers, 1995). Due to its subject range, this work should cover the pioneering paper by Jerzy Łoś.

10 Peter Øhrstrøm, Per Hasle, “The significance of the contributions of A. N. Prior and Jerzy Łoś in the early history of modern temporal logic", in: Logic and Philosophy of Time: Further Themes from Prior, vol. 2, eds. Patrick Blackburn, Per Hasle, Peter Øhrstrøm (Aalborg: Aalborg University Press, 2019), 31-40. 
even social contexts, then all these components (or even more) might appear in one language. From here, there is just one step to the multi-agent systems. ${ }^{11}$ If, however, we manage to provide an intuitive semantics for these applications that is not based on possible worlds, then, perhaps, we can take two steps forward and something totally new will emerge from the heritage of Jerzy Łośs Philosophical Logic.

\section{References}

Goble Lou (ed.). 2001. The Blackwell Guide to Philosophical Logic. Hoboken: WileyBlackwell.

Hiż Henryk. 1951. "Review: Jerzy Łoś, Foundations of the Methodological Analysis of Mill's Canons". Journal of Symbolic Logic 16: 58-59.

Jarmużek Tomasz, Aleksander Parol. 2019. "On Some Language Extension of Logic MR: A Semantic and Tableau Approach”. Roczniki Filozoficzne 68, 4: 345-366.

Jarmużek Tomasz, Andrzej Pietruszczak. 2004. "Completeness of Minimal Positional Calculus". Logic and Logical Philosophy 13: 147-162.

Jarmużek Tomasz, Marcin Tkaczyk. 2015. "Jerzy Łoś and the origin of temporal logic". In: Handbook of the $5^{\text {th }}$ World Congress and School on Universal Logic, eds. J.-Y. Beziau et al., 368-369. Istanbul, Turkey: Istanbul University.

Jarmużek Tomasz, Marcin Tkaczyk. 2015. Normalne logiki pozycyjne. Lublin: Towarzystwo Naukowe KUL.

Jarmużek Tomasz, Marcin Tkaczyk. 2019. "Expressive Power of the Positional Operator R: A Case Study in Modal Logic and Modal Philosophy". Ruch Filozoficzny (Philosophical Movement) LXXV, 2: 91-107.

Jarmużek Tomasz. 2006. "Rekonstrukcje rozumowania Diodora Kronosa w ontologii czasu punktowego" ("Reconstruction of Diodorus Cronus' argument in frame of ontology of time consisted of points"). Analiza i Egzystencja 3: 197-215.

Jarmużek Tomasz. 2007. "Minimal Logical Systems with R-operator: Their Metalogical Properties and Ways of Extensions". In: Perspectives on Universal Logic, eds. J. Bézieau, A. Costa-Leite, 319-333. Monza: Polimetrica International Scientific Publisher.

${ }_{11}$ In practice, the possibility of there being several such contexts has already been hinted at through an open list of context components in Jacek Malinowski, Krzysztof Pietrowicz, Joanna Szalacha-Jarmużek, "Logic of social ontology and Lośs operator", Logic and Logical Philosophy 29 (2020): 239-258. 
Jarmużek Tomasz. 2013. Jutrzejsza bitwa morska. Rozumowanie Diodora Kronosa. Toruń: Wydawnictwo Naukowe UMK.

Jarmużek Tomasz. 2018. On the Sea Battle Tomorrow That May Not Happen. A Logical and Philosophical Analysis of the Master Argument. Berlin-Warsaw: Peter Lang Publishing.

Karczewska Anna Maria. 2018. "Maximality of the Minimal R-logic". Logic and Logical Philosophy 27: 193-203.

Klonowski Mateusz, Rafał Palczewski. 2020. "Epistemic Contextualism and Positional Logic". Studia z Historii Filozofii XI, 3: 67-104.

Klonowski Mateusz, Krzysztof Krawczyk. 2019. "Problem wszechwiedzy logicznej. Krytyka nienormalnych światów i propozycja nowego rozwiązania" "“The problem of logical omniscience. The critique of non-normal worlds and the proposition of new solution"). Filozofia Nauki 27, 1:27-48.

Lechniak Marek. 1988. "Logika epistemiczna Jerzego Łosia a teoria racjonalnego zachowania" ("Epistemic logic of Jerzy Łoś and the theory of rational behaviour"). Roczniki Filozoficzne 26, 1: 79-91.

Lechniak Marek. 2020. "Jerzy Łošs Epistemic Logic and the Origins of Epistemic Logics”. Studia z Historii Filozofii XI, 3: 21-49.

Łoś Jerzy. 1947. "Podstawy analizy metodologicznej kanonów Milla". Annales Universitatis Mariae Curie-Skłodowska, 2.5. F, 269-301. Lublin.

Łoś Jerzy. 1948. "Logiki wielowartościowe a formalizacja funkcji intensjonalnych". Kwartalnik Filozoficzny XVII, 1-2: 59-78. Kraków.

Łoś Jerzy. 1977. "The foundations of a methodological analysis of Mill's methods". In: Twenty-Five Years of Logical Methodology in Poland, eds. Marian Przełęcki, Ryszard Wójcicki, 291-325. Dordrecht: D. Reidel Publishing Company.

Malinowski Jacek, Krzysztof Pietrowicz, Joanna Szalacha-Jarmużek. 2020. "Logic of Social Ontology and Łośs operator". Logic and Logical Philosophy 29: 239-258.

Øhrstrøm Peter, Per Hasle. 1995. Temporal Logic: From Ancient Ideas to Artificial Intelligence. Dordrecht: Kluwer Academic Publishers.

Øhrstrøm Peter, Per Hasle. 2019. “The Significance of the Contributions of A. N. Prior and Jerzy Łoś in the Early History of Modern Temporal Logic". In: Logic and Philosophy of Time: Further Themes from Prior. Vol. 2, eds. Patrick Blackburn, Per Hasle, Peter Øhrstrøm, 31-40. Aalborg: Aalborg University Press.

Parol Aleksander. 2020. "The Influence of Jerzy Łoś on Early Developments in Temporal Logic". Studia $z$ Historii Filozofii XI, 3: 105-126.

Pietrowicz Krzysztof, Joanna Szalacha-Jarmużek. 2020. "Going Beyond the Dichotomy. Problems of Contemporary Sociology in the Context of the Proposals by Jerzy Łoś". Studia z Historii Filozofii XI, 3: 51-65.

Prior Arthur. 1955. Formal Logic. Oxford: Clarendon Press.

Prior Arthur. 1967. Past, Present and Future. Oxford: Clarendon Press. 
Rescher Nicholas. 1968. "Assertion Logic". In: Nicholas Rescher. Topics in Philosophical Logic. Dordrecht-Holland: D. Reidel Publishing, 250-286.

Rescher Nicholas. 1971. Temporal Logic. New York: Springer Verlag.

Suszko Roman. 1949. "Review: Jerzy Łoś, Many-Valued Logics and Formalization of Intensional Functions". Journal of Symbolic Logic 14: 64-65.

Tkaczyk Marcin, Tomasz Jarmużek. 2019. "Jerzy Łoś Positional Calculus and the Origin of Temporal Logic". Logic and Logical Philosophy 28: 259-276.

Tkaczyk Marcin. 2007. "Zmienna czasowa w starożytnej i średniowiecznej teorii zdań warunkowych". Roczniki Filozoficzne 55, 2: 99-121.

Tkaczyk Marcin. 2013. "Negation in Weak Positional Calculi". Logic and Logical Philosophy 22: 3-19.

Tkaczyk Marcin. 2014. "Logika temporalna”. In: Metodologiczne i teoretyczne problemy kognitywistyki, eds. J. Woleński, A. Dąbrowski, 309-348. Kraków: Copernicus Center Press.

Tkaczyk Marcin. 2015. "Spurious Confusion in Temporal Logic". Logic and Logical Philosophy 24: 201-216.

Abstract: In the introduction, we discuss the inadequate reception of Polish scientists and scholars in the world of scientific and academic ideas. This nonreception can be attributed to the tragic historical situation of the country - the Hecatomb suffered by Poland. The philosophical logic heritage of Jerzy Łoś is one such forgotten discovery. The present volume is devoted to this very heritage as well as its reception. The four works printed herein are discussed in the introduction. Although they deal with different problems and their approach to the problem varies (some are of a historical nature while others propose some scientific activities), they all have one thing in common: the use of realisation operator. The operator is a logical connective that makes it possible to express various ideas. The realisation operator was introduced by Jerzy Łoś.

Keywords: Jerzy Łoś, epistemic logic, positional logic, temporal logic, realisation operator, Polish School of Logic 